\title{
Impaired Functions of Lymphocytes on Nitric Oxide Production in Endotoxin- Tolerant Mice
}

\author{
Young-Gi Gil and Mi-Kyung Kang * \\ Department of Anatomy, Kosin University College of Medicine, Busan 602-702, Korea \\ ${ }^{1}$ Institute for Medical Science, Kosin University College of Medicine, Busan 602-702, Korea
}

Received August 10, 2008 /Accepted September 11, 2008

\begin{abstract}
In this study, nitric oxide (NO) production in a macrophage-lymphocyte co-culture system was used to assess the cytokine producing capability of cells during endotoxin tolerance in mice. Incubation of peritoneal macrophages with interferon- $\gamma($ IFN- $\gamma$ ) in the presence of lipopolysaccharide (LPS) augmented NO synthesis. Exogenous tumor necrosis factor- $\alpha$ (TNF- $\alpha$ ) could also replace LPS for the stimulation of NO production. Macrophages co-cultured with splenic lymphocytes showed augmented NO synthesis by LPS alone. However, pretreatment of mice with $2.5 \mathrm{mg} / \mathrm{kg}$ LPS completely prevented the lethality and the increase of blood TNF- $\alpha$ and IFN- $\gamma$ after the second challenge with a lethal dose of LPS. In addition, when macrophages prepared from LPS-tolerant mice were co-cultured with normal splenocytes, LPS also could not induce the production of NO, even in the presence of exogenous TNF- $\alpha$. Moreover, when normal macrophages were co-cultured with splenocytes obtained from LPS-tolerant mice, stimulation with LPS could not evoke the NO production enhancement. However, this down-regulation was able to reverse by exogenous IFN- $\gamma$ or concanavalin A (ConA), a stimulator of IFN- $\gamma$ production. Our results indicate that not only macrophages but also lymphocytes contribute to LPS tolerance. As INF- $\gamma$ can enhance the expression of TNF- $\alpha$, the decrease of INF- $\gamma$ synthesis from lymphocytes may orchestrate with the decrease of TNF- $\alpha$ synthesis from LPS-tolerant macrophages for the production of tolerant state and the prevention of excessive inflammation. Therefore, LPS tolerance may be exploited for prophylaxis of severe sepsis in patients at risk.
\end{abstract}

Key words : Endotoxin tolerance, interferon- $\gamma$, lymphocyte, lipopolysaccharide, nitric oxide

\section{Introduction}

It is well known that the fatal complications of gram-negative sepsis are the result of an over-stimulation of the host's immune response, which is triggered by lipopolysaccharide (LPS) in the outer membrane of gram-negative bacteria [2]. LPS activates primary inflammatory cells such as monocytes or macrophages to produce a variety of cytokines, leading to a systemic inflammatory response [6]. These phenomena lead to the delicate unbalance of cytokine network and may become induces clinical illness. In humans, this systemic release of cytokines is associated with multiple organ failure and death from septic shock [2]. Among the cytokines, tumor necrosis factor- $\alpha$ (TNF- $\alpha$ ), interleukin (IL)- $1 \beta$, and IL-6 have been implicated as important factors in the pathophysiology of septic shock [21].

The hyperinflammatory phase of sepsis is generally exhausted after a few days. The late stage of sepsis is charac-

\section{*Corresponding author}

Tel : +82-51-990-6412, Fax : +82-51-990-5081

E-mail : receptacle@hanmail.net terized by anergy of the immunocompetent cells [4]. Monocytes from this late-stage sepsis produced diminished amounts of TNF- $\alpha$, IL-1, IL- 6 , and IL-10, but not IL-1 receptor antagonist (IL-RA) when stimulated ex vivo with LPS [23]. This cytokine release pattern was comparable with the one seen in experimentally LPS-desensitized monocytes in vitro [22]. This phenomenon is called endotoxin tolerance or immunoparalysis [10]. Although this endotoxin tolerance may contribute to the enhanced susceptibility to infections and late mortality of patients who survive the initial acute phase of sepsis syndrome [20], it is thought to be an adaptive mechanism designed to protect the host form further inflammatory injury.

The molecular mechanisms leading to endotoxin tolerance have been well studied but not completely delineated. The hyporesponsiveness to the second challenge of LPS is associated with reduced production of TNF- $\alpha$ [25]. Macrophages exposed to LPS are unable to synthesize TNF- $\alpha$ mRNA when they are subsequently challenged with LPS, suggesting that the transcription process is down-regulated [33]. Some investigators have demonstrated that the suppressed-release of 
interferon- $\gamma$ (IFN- $\gamma$ ) observed in this condition [8,17]. In addition, Varma and his colleagues [29] reported that the suppression of IFN- $\gamma$ production in LPS-tolerant mice is largely due to macrophage dysfunction. Furthermore, IFN- $\gamma$ has been shown to enhance the expression of TNF- $\alpha$ and cellular receptors for TNF- $\alpha$ in macrophages $[13,28]$. These results suggest that the balance of cytokines including TNF- $\alpha$ and IFN- $\gamma$ are more important in the induction and further response in endotoxin tolerance. However, there are little reports about the lymphocytes, major IFN- $\gamma$ producing cells in the body, during the LPS tolerant state in vivo.

In sepsis, hypotension and organ injury arises as the results of decreased vascular resistance evoked by elevated nitric oxide (NO) derived from an nitric oxide synthase (NOS) and the vasodilatory shock resulted in the decreased tissue perfusion and ischemia [30,31]. Recent reports show that development of tolerance to LPS in rats is associated with a totally reduced ability of LPS to induce NOS within $48 \mathrm{~h}$ after first LPS treatment, suggesting the involvement of NO in development of tolerance to endotoxin [26], Furthermore, LPS act to release TNF- $\alpha$ and IFN- $\gamma$, these cytokines cause potent endogenous inducers of NO with iNOS expression from macrophages [16,19]. It may indicate the existence of specific feedback regulatory loop between cytokines and NO. Therefore, the interplay between LPS and cytokines including IFN- $\gamma$ and TNF- $\alpha$ to enhance the NO production can be a good model system to assess the IFN- $\gamma$ producing capability of cells.

In this study, we prepared macrophages or splenic lymphocytes from LPS-tolerant mice, and measured NO production in a macrophage-lymphocyte co-culture system stimulated with LPS to assess the cytokine producing capability of cells during the endotoxin tolerance in mice.

\section{Materials and Methods}

\section{Experimental materials}

LPS (Escherichia coli serotype 0127:B8), TNF-a, IFN- $\gamma$, concanavalin A (ConA), sulfanilamide, and N-(1-naphthyl) ethylenediamine dihydrochloride were supplied by Sigma (St. Louis, MO, USA). RPMI 1640 medium, fetal bovine serum (FBS), Hanks' balanced salt solution (HBSS), penicillin-streptomycin, and trypsin-EDTA were purchased from Gibco BRL (Bethesda, MD, USA). All cell culture reagents were obtained from Invitrogen Corp (Carlsbad, CA, USA) and the other reagents of analytical grade were pur- chased locally. For experiment in vivo, LPS was dissolved in sterile physiological saline at a concentration of $5 \mathrm{mg} / \mathrm{ml}$ as a stock solution and stored at $-70^{\circ} \mathrm{C}$.

\section{Animal treatment}

Male ICR mice (6 weeks old, 20-25 g) were used in this study. For the induction of tolerance, ICR mice were injected with $2.5 \mathrm{mg} / \mathrm{kg}$ E. coli serotype 0127:B8 LPS (Sigma) intraperitoneally $24 \mathrm{hr}$ prior to the challenge with $25 \mathrm{mg} / \mathrm{kg}$ of same LPS intravenously. Control animals were administrated to saline.

\section{Effect on lethality and serum TNF- $\alpha$ and IFN- $\gamma$} levels

The lethality of mice was monitored at $48 \mathrm{hr}$ after final LPS challenge in each treated group. Blood samples were obtained from mice by heart puncture at 1.5 or $6 \mathrm{hr}$ after the last LPS administration for the measurement of TNF- $\alpha$ and IFN- $\gamma$ levels in plasma. The serum TNF- $\alpha$ and IFN- $\gamma$ levels were assayed using Quantkine ${ }^{\mathrm{TM}} \mathrm{M}$ enzyme-linked immunosorbent assay (ELISA) kits (R\&D, Minneapolis, MN, USA) according to the manufacturer's protocol. The detection limits of TNF- $\alpha$ and IFN- $\gamma$ ELISAs are less than 5 $\mathrm{pg} / \mathrm{ml}$.

\section{Preparation of peritoneal exudate macrophages}

Mouse macrophages were obtained from ICR mice injected with $2 \mathrm{ml}$ of sterile 3\% thioglycolate (Difco) [18]. Four days after injection, peritoneal exudate cells were harvested by peritoneal lavage with $6 \mathrm{ml}$ of ice-cold phosphate buffered saline (PBS) per mouse. These cells were washed twice and then suspended at $5 \times 10^{6}$ cells/ml in RPMI 1640 medium supplemented with $10 \%$ FBS, $100 \mathrm{IU} / \mathrm{ml}$ penicillin G, and $5 \mu \mathrm{g} / \mathrm{ml}$ streptomycin (working medium). After $2 \mathrm{hr}$ incubation in $75 \mathrm{~cm}^{2}$ culture flasks at $37^{\circ} \mathrm{C}$ in a humidified 95\% air $/ 5 \% \mathrm{CO}_{2}$ atmosphere, nonadherent cells were removed by repeated washing with ice-cold PBS. Adherent cells (peritoneal exudate macrophage) were harvested using a cell scraper and resuspended at $1 \times 10^{6}$ cells $/ \mathrm{ml}$ in working medium for further experiments.

\section{Preparation of spleen lymphocytes}

After cervical dislocation of ICR mice, spleens were excised aseptically, and placed in a Petri dish containing HBSS. Using two glass slides, a suspension of spleen cells was prepared and washed twice with ice-cold HBSS. After lysis of 
erythrocytes with $17 \mathrm{mM}$ tris- $\mathrm{HCl}, \mathrm{pH} 7.2$, containing 0.144 $\mathrm{M}$ ammonium chloride for $5 \mathrm{~min}$, cells were overlaid on HBSS containing $5 \%$ albumin, and pelleted by centrifugation at $200 \times \mathrm{g}$ for $10 \mathrm{~min}$ [18]. Cells were resuspended at $5 \times 10^{6}$ cells $/ \mathrm{ml}$ in working medium for further experiments.

\section{Cell culture}

Macrophages $\left(4 \times 10^{5}\right.$ cells $)$ were cultured with working medium (total volume of $400 \mu \mathrm{l}$ ) in 24-well culture plate with or without various reagents including LPS from Escherichia coli serotype 0127:B8 (50 ng/ml, Sigma), recombinant mouse IFN- $\gamma$ (5 U/ml, Sigma), TNF- $\alpha$ (500 U/ml, Sigma), and ConA $\left(2 \mu \mathrm{g} / \mathrm{ml}\right.$, Sigma). In other experiments, splenocytes $\left(2 \times 10^{6}\right.$ cells) were co-cultured with macrophages. For the induction of tolerance, mice were injected with $2.5 \mathrm{mg} / \mathrm{kg}$ LPS intraperitoneally $24 \mathrm{hr}$ prior to the cell preparation.

\section{Nitrite measurement}

To measure the concentration of NO produced in mice, the stable conversion product of $\mathrm{NO}$, nitrite $\left(\mathrm{NO}_{2}^{-}\right)$, was measured [7,11]. Following $48 \mathrm{hr}$ incubation in 24-well plates at $37^{\circ} \mathrm{C}$ in a humidified $95 \%$ air $/ 5 \% \mathrm{CO}_{2}$ atmosphere, nitrite concentration was measured in the cell-free culture supernatant. Briefly, $50 \mu \mathrm{l}$ aliquots of the culture supernatants, dispensed into 96-well microtiter plates (flat bottom), were incubated with $100 \mu \mathrm{l}$ of a 1:1 mixture of $1 \%$ sulfanilamide (Sigma) in $30 \%$ acetic acid and $0.1 \%$ $\mathrm{N}$-(1-naphthyl) ethylenediamine dihydrochloride (Sigma) in $60 \%$ acetic acid at room temperature. After $5 \mathrm{~min}$, absorbance was measured at $540 \mathrm{~nm}$ using a microtiter plate reader (MR 700, Dynatech Laboratories Inc.). Concentrations were determined from a linear standard curve obtained from serial concentrations of sodium nitrite (Sigma) in working medium. Results of triplicate measurements were presented as mean \pm SD.

\section{Immunoblot analysis for iNOS}

Cells were homogenized in $100 \mu \mathrm{l}$ of ice-cold lysis buffer (20 mM HEPES, pH 7.2, 1\% Triton X-100, 10\% glycerol, 1 $\mathrm{mM}$ phenylmethylsulfonyl fluoride, $10 \mu \mathrm{g} / \mathrm{ml}$ leupeptin, 10 $\mu \mathrm{g} / \mathrm{ml}$ aprotinin). The homogenates was centrifuged at $15,000 \mathrm{~g}$ at $4^{\circ} \mathrm{C}$ for $10 \mathrm{~min}$ and and the total protein content was determined. Equal amounts $(30 \mathrm{mg})$ of protein extracts in a lysis buffer were subjected to 10\% SDS-polyacrylamide gel analysis and transferred to nitrocellulose sheets (Schleicher \& Schuell, Dassel, Germany). The nitrocellulose paper was blocked in PBS containing 5\% skim milk at $4^{\circ} \mathrm{C}$ for $1 \mathrm{hr}$. After washing with wash buffer (PBS containing $0.1 \%$ skin milk and $0.05 \%$ Tween 20 ), the membrane was then incubated with anti-iNOS antibody (1:1,000 dilution, BD Bioscience, Franklin Lakes, NJ, USA) and anti- $\beta$-Actin (1:5,000 dilution, Sigma) at room temperature for $4 \mathrm{hr}$. After washing, the membrane was treated with secondary antibody anti-rabbit IgG conjugated to an alkaline phosphatase (1:1,000 dilution, Sigma) at room temperature for $1 \mathrm{hr}$. The binding of antibody was detected using a BCIP/NBT solution (Pierce Chemical Co. Rockford, IL, USA). Relative band intensities were determined by Quality-one 1-D analysis software (BioRad, Hercules, CA, USA).

\section{Statistical analysis}

All data are expressed as means $\pm S D$ and the differences were analyzed by One-way analysis of variance (ANOVA). Values of $\mathrm{P}<0.05$ were considered to be significant.

\section{Results}

Effect of LPS tolerance on mortality and production of $\mathrm{TNF}-\alpha$ and $\mathrm{IFN}-\gamma$ in mouse

Mice were injected with $2.5 \mathrm{mg} / \mathrm{kg} \quad$ E. coli LPS intraperitoneally. After $24 \mathrm{hr}, 25 \mathrm{mg} / \mathrm{kg}$ of the same LPS was administered intravenously, and then lethality was monitored at $48 \mathrm{hr}$ after final injection. All the 5 control mice which had received PBS instead of prior LPS died after a single dose of $25 \mathrm{mg} / \mathrm{kg}$ LPS. However, all mice pretreated with the low dose of LPS survived. In addition, only $0.3 \pm 0.2$ $\mathrm{ng} / \mathrm{ml}$ of serum TNF- $\alpha$ was observed at $1.5 \mathrm{hr}$ after the last LPS administration in LPS-tolerant mice, while 17.0 \pm 2.5 $\mathrm{ng} / \mathrm{ml}$ was detected in control mice (Table 1 ). In addition, after LPS challenge, serum TNF- $\alpha$ and serum IFN- $\gamma$ level at $6 \mathrm{hr}$ was also markedly decreased in LPS-tolerant mice (data not shown). These finding demonstrated that the repeated exposure of LPS results in induction of endotixin tolerance, which is attenuated the release of TNF- $\alpha$ and IFN- $\gamma$.

\section{Release of nitrite by mouse peritoneal macrophages and lymphocytes}

To investigate the effects of cytokines on NO production in mouse peritoneal macrophages, nitrite concentrations, as an indicator for NO formation, were measured in vitro culture medium system. Because of the short half-life of NO in biological fluids, the measurement of nitrite, as the stable 
Table 1. Lethality and the production of TNF- $\alpha$ and IFN- $\gamma$ by LPS challenge after prior desensitization with small amount of LPS

\begin{tabular}{cccr}
\hline & $\begin{array}{c}\text { Lethality } \\
\text { (dead/total) }\end{array}$ & $\begin{array}{c}\text { TNF- } \alpha \\
(\mathrm{ng} / \mathrm{ml})\end{array}$ & $\begin{array}{c}\text { IFN- } \gamma \\
(\mathrm{ng} / \mathrm{ml})\end{array}$ \\
\hline Control & $5 / 5$ & $17.0 \pm 2.5$ & $104.2 \pm 10.1$ \\
LPS-treated & $0 / 5$ & $0.3 \pm 0.2^{*}$ & $5.5 \pm 0.3^{*}$ \\
\hline
\end{tabular}

For the induction of tolerance, mice ( 5 for each group) were injected with $2.5 \mathrm{mg} / \mathrm{kg}$ E. coli serotype 0127:B8 LPS intraperitoneally $24 \mathrm{hr}$ prior to the challenge with $25 \mathrm{mg} / \mathrm{kg}$ of same LPS. Lethality was monitored at $48 \mathrm{hr}$ after final LPS administration. TNF- $\alpha$ and IFN- $\gamma$ were measured in blood at 1.5 and $6 \mathrm{hr}$ after the last LPS administration, respectively. Data were expressed as mean \pm SE. ${ }^{*} p<0.01$.

metabolites of $\mathrm{NO}$, is widely used for $\mathrm{NO}$ determination in fluids [7,11]. As shown in Fig. 1, combination of LPS and IFN- $\gamma$ significantly increased NO production of macrophages. This increase can be mimicked by a combination of TNF- $\alpha$ and IFN- $\gamma$, even in the absence of LPS. However, LPS, TNF- $\alpha$ or IFN- $\gamma$ alone were not able to increase nitric oxide production.

In addition, to replace IFN- $\gamma$ in our NO induction system, peritoneal macrophages were co-cultured with $2 \times 10^{6}$ splenocytes and stimulated with LPS, TNF- $\alpha$ or IFN- $\gamma$. Stimulation of LPS alone can cause the increase of NO production in

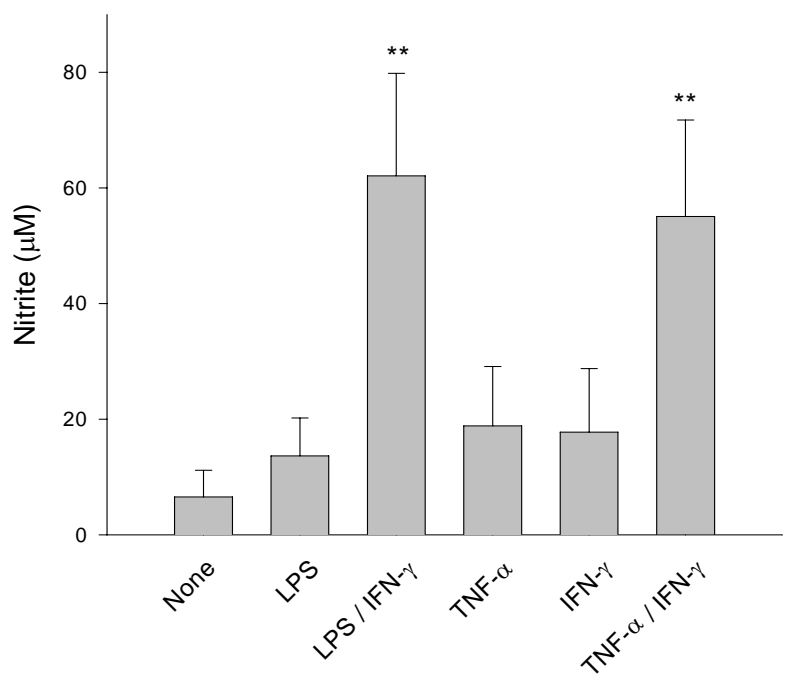

Fig. 1. Induction of NO synthesis in peritoneal macrophages by LPS, TNF- $\alpha$ and IFN- $\gamma$. Macrophages $\left(4 \times 10^{5}\right.$ cells $)$ were cultured in 24-well culture plate with LPS (50 $\mathrm{ng} / \mathrm{ml})$, TNF- $\alpha(500 \mathrm{U} / \mathrm{ml})$, and/or IFN- $\gamma(5 \mathrm{U} / \mathrm{ml})$. Following $48 \mathrm{hr}$ incubation, nitrite concentration was measured in the cell-free culture supernatants as a reflection of NO synthesis. Results of triplicate samples were expressed as mean $\pm \mathrm{SD}$. ${ }^{* *} p<0.01$ vs none.

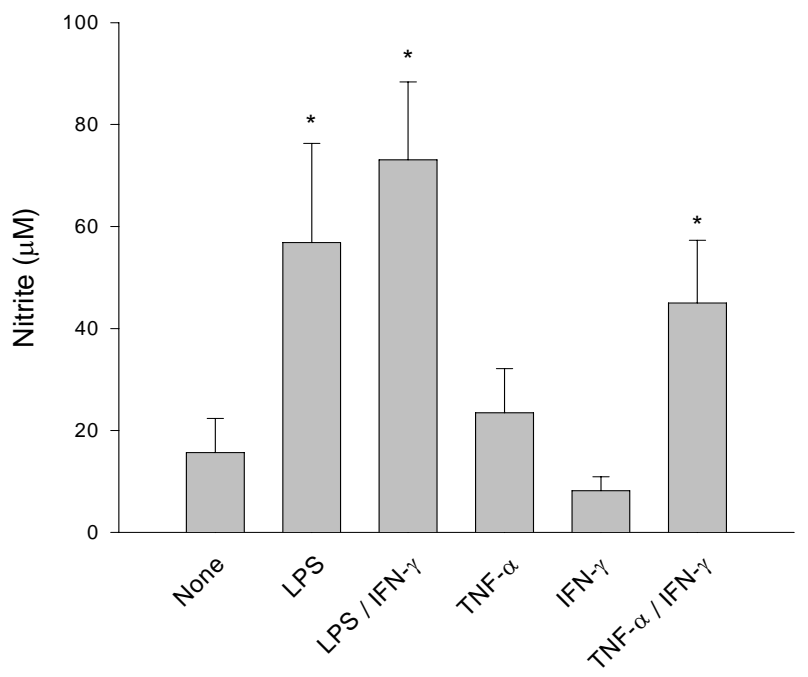

Fig. 2. Induction of $\mathrm{NO}$ synthesis in peritoneal macrophages co-cultured with splenocytes by LPS, TNF- $\alpha$ and IFN- $\gamma$. Macrophages $\left(4 \times 10^{5}\right.$ cells) were co-cultured with splenocytes $\left(2 \times 10^{6}\right.$ cells $)$ in 24 -well culture plate and stimulated with LPS $(50 \mathrm{ng} / \mathrm{ml})$, TNF- $\alpha(500 \mathrm{U} / \mathrm{ml})$, and/or IFN- $\gamma$ (5 U/ml). Following $48 \mathrm{hr}$ incubation, nitrite concentration was measured in the cell-free culture supernatants as a reflection of NO synthesis. Results of triplicate samples were expressed as mean \pm SD. ${ }^{*} p<0.05$ vs none.

co-culture system. In the absence of LPS, this increase of NO production can be mimicked by a combination of TNF- $\alpha$ and IFN- $\gamma$ (Fig. 2). These results suggest that stimulation of lymphocytes by LPS evokes the enhanced release of IFN- $\gamma$.

\section{Release of nitrite by LPS-desensitized macrophages and lymphocytes}

To evaluate the condition of macrophages and lymphocytes on NO production during LPS-tolerant states, macrophages and splenocytes were obtained from LPS-tolerant mice induced by $2.5 \mathrm{mg} / \mathrm{kg}$ LPS for $24 \mathrm{hr}$. LPS-tolerance mice induced-macrophages and -splenocytes were co-cultured with normal-macrophages and -splenocytes and nitrite concentrations were measured in culture medium. When LPS-tolerance mice induced-macrophages were stimulated by LPS, LPS alone could not increase the NO production. Furthermore, addition of exogenous TNF- $\alpha$ and/or IFN- $\gamma$ also could not evoke the increased NO production by LPS-tolerant macrophages (Fig. 3). It was suggested that the TNF- $\alpha$ producing capability of macrophages was down-regulated by LPS pretreatment.

As shown in Fig. 4, when normal macrophages were co-cultured with splenocytes derived from LPS-pretreated 


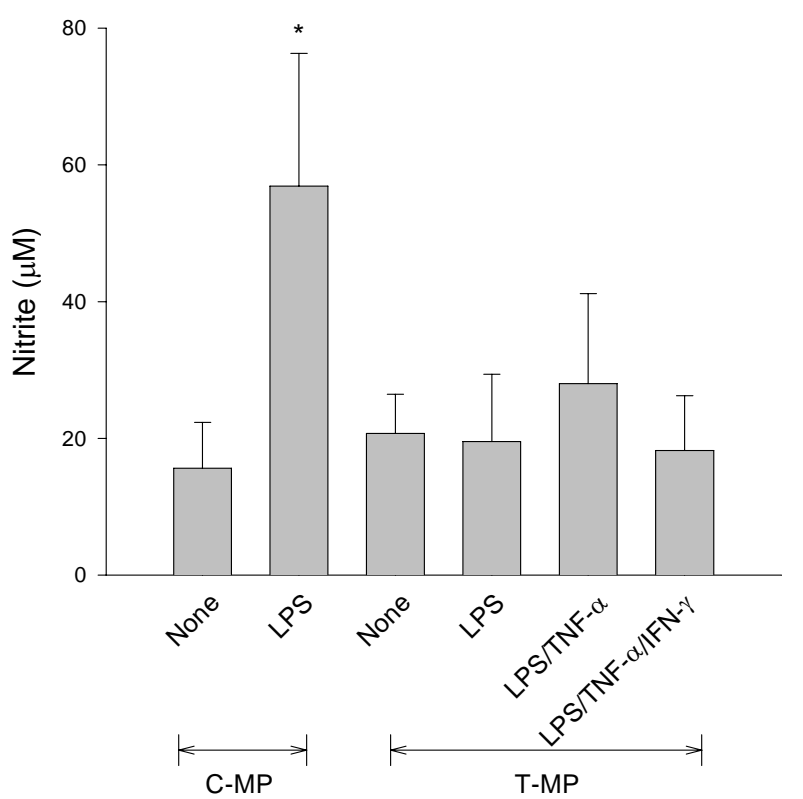

Fig. 3. Induction of NO synthesis in LPS-desensitized macrophages co-cultured with splenocytes by LPS, TNF- $\alpha$ and IFN- $\gamma$. Mice were injected with $2.5 \mathrm{mg} / \mathrm{kg}$ LPS intraperitoneally $24 \mathrm{hr}$ prior to the preparation of macrophage. Control (C-MP) or LPS-pretreated (T-MP) macrophages $\left(4 \times 10^{5}\right.$ cells $)$ were co-cultured with control splenocytes $\left(2 \times 10^{6}\right.$ cells $)$ in 24 -well culture plate and stimulated with LPS $(50 \mathrm{ng} / \mathrm{ml})$, TNF- $\alpha(500 \mathrm{U} / \mathrm{ml})$, and/or IFN- $\gamma$ (5 $\mathrm{U} / \mathrm{ml}$ ). Following $48 \mathrm{hr}$ incubation, nitrite concentration was measured in the cell-free culture supernatants as a reflection of NO synthesis. Results of triplicate samples are expressed as mean \pm SD. ${ }^{*} p<0.05$ vs none.

mice, NO production dose not increase by LPS stimulation. It was demonstrated that the INF- $\gamma$ producing capability of splenocytes was also down-regulated by prior treatment with LPS. This down-regulation could be compensated by exogenous IFN- $\gamma$. Furthermore, ConA, a stimulant of IFN- $\gamma$ production from lymphocytes, also counteracted the down-regulation of IFN- $\gamma$ production by prior LPS administration (Fig. 4).

To identify whether the relieving effect of ConA was exerted only on splenocytes, the effect of ConA was determined on macrophages stimulated by LPS and IFN- $\gamma$. As shown in Fig. 5, addition of ConA did not cause any increase of $\mathrm{NO}$ production from macrophages stimulated by LPS and IFN- $\gamma$. However, in the macrophage-splenocyte co-culture system, ConA greatly increased the NO production by LPS stimulation. These finding suggest that ConA-induced INF- $\gamma$ of splenocytes amplify the production of TNF- $\alpha$ and leading to the enhancement of NO production in macrophages.

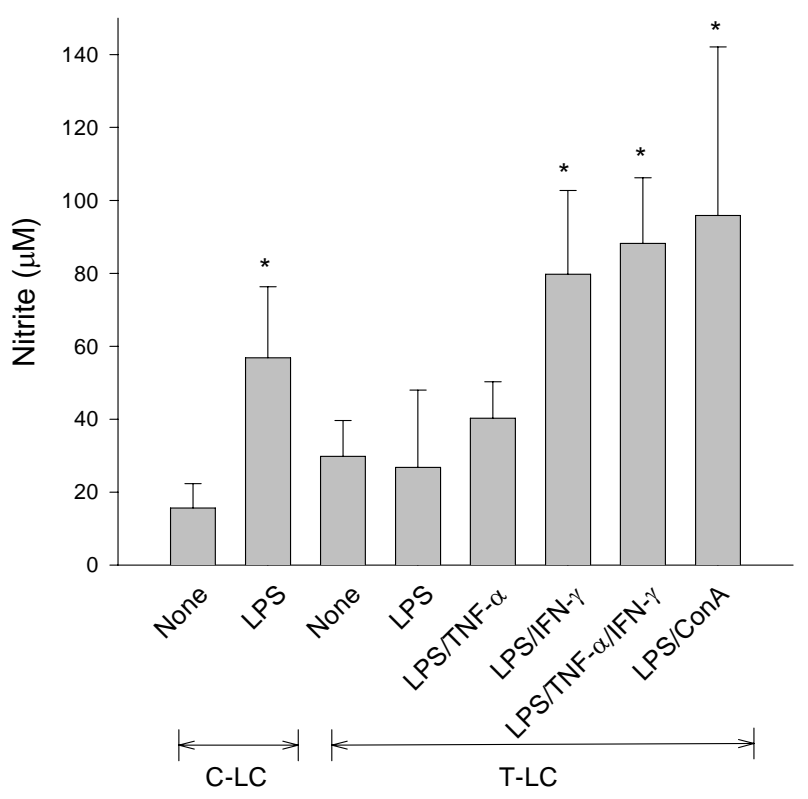

Fig. 4. Induction of NO synthesis in control macrophages co-cultured with LPS-desensitized splenocytes by LPS, TNF- $\alpha$, IFN- $\gamma$, and ConA. Mice were injected with $2.5 \mathrm{mg} / \mathrm{kg}$ LPS intraperitoneally $24 \mathrm{hr}$ prior to the preparation of splenocytes. Control macrophages $\left(4 \times 10^{5}\right.$ cells) were co-cultured with control (C-LC) or LPS-pretreated (T-LC) splenocytes $\left(2 \times 10^{6}\right.$ cells $)$ in 24 -well culture plate and stimulated with LPS $(50 \mathrm{ng} / \mathrm{ml}), \mathrm{TNF}-\alpha(500 \mathrm{U} / \mathrm{ml})$, IFN$\gamma(5 \mathrm{U} / \mathrm{ml})$, and/or ConA $(2 \mu \mathrm{g} / \mathrm{ml})$. Following $48 \mathrm{hr}$ incubation, nitrite concentration was measured in the cell-free culture supernatants as a reflection of $\mathrm{NO}$ synthesis. Results of triplicate samples were expressed as mean \pm SD. ${ }^{*} p<0.05$ vs none of each C-LC and T-LC.

\section{Discussion}

Endotoxin tolerance constitutes a transient state of low-responsiveness to various bioactivities of endotoxins. This phenomenon can be induced by a single or repeated injection of low amounts of endotoxin in humans and experimental animals [10]. The molecular mechanism for endotoxin tolerance was turned out that macrophages are of primary importance for the development of tolerance [6]. Furthermore, it has been shown that macrophages can be rendered refractory towards several endotoxin activities including TNF$\alpha$ synthesis by pretreatment with small amount of endotoxins [23].

In our study, pretreatment of mice with $2.5 \mathrm{mg} / \mathrm{kg}$ LPS completely prevented lethality after the second challenge with lethal dose of LPS, indicating that LPS tolerance has been induced. Serum TNF- $\alpha$ level was markedly decreased in LPS-tolerant mice, in agreement with earlier report that 


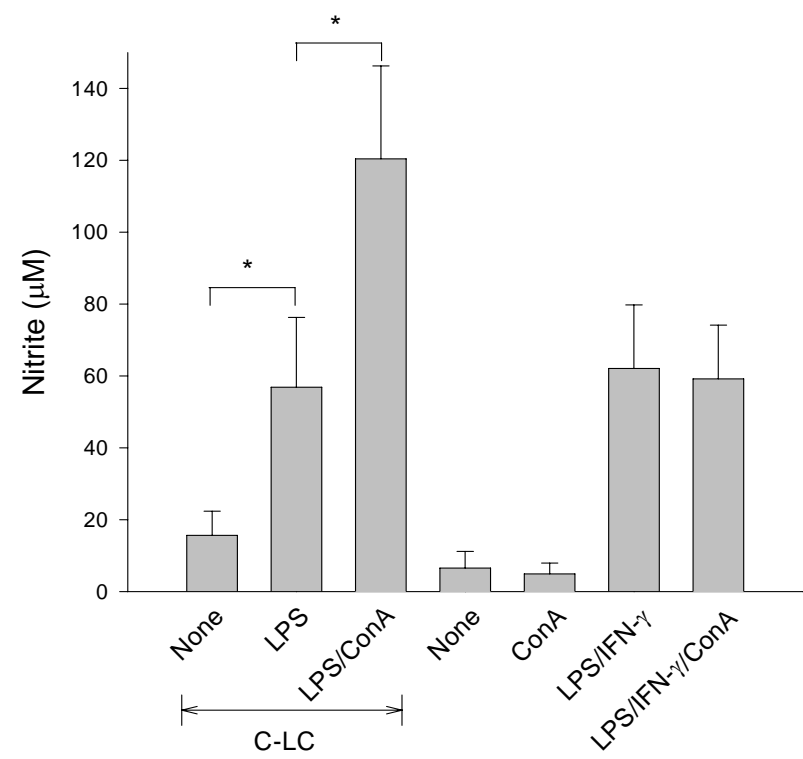

Fig. 5. Induction of NO synthesis in peritoneal macrophages alone or co-cultured with splenocytes by LPS, IFN- $\gamma$, and ConA. Macrophages $\left(4 \times 10^{5}\right.$ cells $)$ were cultured alone or with control splenocytes (C-LC, $2 \times 10^{6}$ cells) in 24-well culture plate and stimulated with LPS (50 ng/ml), IFN- $\gamma$ $(5 \mathrm{U} / \mathrm{ml})$, and/or ConA $(2 \mu \mathrm{g} / \mathrm{ml})$. Following $48 \mathrm{hr}$ incubation, nitrite concentration was measured in the cell-free culture supernatants as a reflection of NO synthesis. Results of triplicate samples were expressed as mean \pm SD. ${ }^{*} p<0.05$.

repression of TNF- $\alpha$ synthesis plays an important role in LPS-tolerance [33]. Furthermore, in LPS-tolerant mice, circulating IFN- $\gamma$ level was also significantly decreased. IFN- $\gamma$ is a pleiotropic cytokine that regulates natural, cell-mediated, and humoral immunity by eliciting a number of biological responses in many different cell types [5]. Several studies indicate that IFN- $\gamma$ can modulate the endotoxin tolerance $[3,22]$, suggesting the importance of delicate balance between cytokines. Incubation of peritoneal macrophages with IFN- $\gamma$ for $48 \mathrm{hr}$ in the presence of LPS augmented NO synthesis by inducible NOS. As LPS can stimulate the synthesis of TNF- $\alpha$ from macrophages [27], exogenous TNF- $\alpha$ could replace LPS for the stimulation of NO production. IFN- $\gamma$, TNF$\alpha$ or LPS alone were not capable of increasing NO synthesis in peritoneal macrophages. IFN- $\gamma$ bioactivity can be easily assayed with above NO production system [12].

LPS also stimulates the production of IFN- $\gamma$ [14]. In this study, we prepared macrophages or splenocytes from LPS-tolerant mice, and measured NO production in macrophage-splenocyte co- culture system stimulated with LPS to assess the cytokine producing capability of cells. IFN- $\gamma$ is thought to be produced primarily by $\mathrm{T}$ lymphocytes and natural killer (NK) cells in response to various stimuli [5]. T-lymphocytes and NK cells constitute $50 \sim 60$ and $\sim 10 \%$ of splenocytes, respectively [1]. Co-culture of macrophages and splenocytes obtained from control mice elicited the augmented NO synthesis by the treatment with LPS alone. When macrophages prepared from LPS-tolerant mice were co-cultured with normal splenocytes, LPS could not induce the production of NO. These results are in agreement with those of other reports that tolerant macrophages were unable to produce TNF- $\alpha$ by LPS stimulation [23,33]. However, prior exposure of macrophages with endotoxin also prevents the induction of NOS by second challenge of LPS in the presence of exogenous TNF- $\alpha$, indicating that both TNF- $\alpha$ synthesis and action are blocked by a prior LPS challenge.

When normal macrophages were co-cultured with splenocytes obtained from LPS-tolerant mice exposed to LPS 24 hr before, stimulation with LPS could not evoke the NO production enhancement. However, this down regulation was able to reverse by exogenous IFN- $\gamma$ or ConA, a stimulator of IFN- $\gamma$ production. It is possible that, after the initial activation by endotoxin, a period exists in which the signaling pathway leading to the production of INF- $\gamma$ in splenic lymphocytes might be refractory to further stimulation by endotoxin, just like the TNF- $\alpha$ synthesis of macrophages. The LPS challenge also causes changes in the composition and the number of splenocytes [15]. Cytokine-induced apoptosis of human NK cells has been described as a novel mechanism to down-regulate the production of INF- $\gamma$ [24]. Actually, decrease in the number of INF- $\gamma$ producing cells might cause the failure in NO production enhancement.

In animals, LPS tolerance is a highly effective mechanism of protection against the lethal syndrome of severe sepsis. LPS tolerance does not lead to down-regulation of all kinds of responses. Some genes including TNF receptor type II, granulocyte-macrophage colony-stimulating factor (GMCSF) and IL-1 $\beta$ are even increased in expression upon secondary stimulation $[9,13]$. Tolerance to LPS is not a passive process that occurs in an exhausted cell; rather, a well-controlled, active process that is orchestrated in order to prevent excessive inflammation.

Our results indicate that LPS tolerance is a phenomenon attributable to not only macrophages but also to INF- $\gamma$ producing lymphoid cells. INF- $\gamma$ has been shown to enhance the expression of TNF- $\alpha$ [13], and amplify LPS-induced shock in animal experiments [3]. The decrease of INF- $\gamma$ syn- 
thesis from LPS-tolerant animal may orchestrate with the decrease of TNF- $\alpha$ for the production of tolerant state. LPS tolerance may be exploited for prophylaxis of severe sepsis in patients at risk [32].

\section{References}

1. Abbas, A. K., A. H. Lichtman and J. S. Pober. 1997. Cellular and Molecular Immunology. W.B. Saunders Co., Philadelphia.

2. Bone, R. C., R. A. Balk, F. B. Cerra, R. P. Dellinger, A. M. Fein, W. A. Knaus, R. M. Schein and W. J. Sibbald. 1992. Definitions for sepsis and organ failure and guidelines for the use of innovative therapies in sepsis. The ACCP/SCCM Consensus Conference Committee. American College of Chest Physicians/Society of Critical Care Medicine. Chest 101, 1644-1655.

3. Bundschuh, D. S., J. Barsig, T. Hartung, F. Randow, W. D. Docke, H. D. Volk and A. Wendel. 1997. Granulocyte-macrophage colony-stimulating factor and IFN-gamma restore the systemic TNF-alpha response to endotoxin in lipopolysaccharide- desensitized mice. J. Immunol. 158, 28622871.

4. Ertel, W., J. P. Kremer, K. Kenney, U. Steckholzer, D. Jarrar, O. Trentz and F. W. Schildberg. 1995. Downregulation of proinflammatory cytokine release in whole blood from septic patients. Blood 85, 1341-1347.

5. Farrar, M. A. and R. D. Schreiber. 1993. The molecular cell biology of interferon-gamma and its receptor. Annu. Rev. Immunol. 11, 571-611.

6. Freudenberg, M. A. and C. Galanos. 1988. Induction of tolerance to lipopolysaccharide (LPS)-D-galactosamine lethality by pretreatment with LPS is mediated by macrophages. Infect. Immun. 56, 1352-1357.

7. Green, L. C., D. A. Wagner, J. Glogowski, P. L. Skipper, J. S. Wishnok and S. R. Tannenbaum. 1982. Analysis of nitrate, nitrite, and [15N]nitrate in biological fluids. Anal. Biochem. 126, 131-138.

8. Heagy, W., C. Hansen, K. Nieman, L. Jorge and J. Rodriguez. 2000. Impaired mitogen-activated protein kinase activation and altered cytokine secretion in endotoxin-tolerant human monocytes. J. Trauma. 49, 1-8.

9. Henricson, B. E., C. L. Manthey, P. Y. Perera, T. A. Hamilton and S. N. Vogel. 1993. Dissociation of lipopolysaccharide (LPS)-inducible gene expression in murine macrophages pretreated with smooth LPS versus monophosphoryl lipid A. Infect. Immun. 61, 2325-2333.

10. Hewett, J. A. and R. A. Roth. 1993. Hepatic and extrahepatic pathobiology of bacterial lipopolysaccharides. Pharmacol. Rev. 45, 382-411.

11. Kang, M. K., Y. E.Yoon, J. Y. Yang, K. B. Kwon, J. W. Park and E. C. Jhee. 2004. Protective effect of retinoic acid on interleukin-1 $\beta$-induced cytotoxicity of pancreatic $\beta$-cells. Mecha. Age. Develop. 125, 483-490.
12. Kim, Y. M. and K. Son. 1996. A nitric oxide production bioassay for interferon-gamma. J. Immunol. Methods 198, 203-209.

13. Koerner, T. J., D. O. Adams and T. A. Hamilton. 1987. Regulation of tumor necrosis factor (TNF) expression: interferon-gamma enhances the accumulation of mRNA for TNF induced by lipopolysaccharide in murine peritoneal macrophages. Cell Immunol. 109, 437-443.

14. Le, J., J. X. Lin, D. Henriksen-DeStefano and J. Vilcek. 1986. Bacterial lipopolysaccharide-induced interferon-gamma production: roles of interleukin-1 and interleukin-2. J. Immunol. 136, 4525-4530.

15. Li, S. P., S. I. Lee and J. E. Domer. 1998. Alterations in frequency of interleukin-2 (IL-2)-, gamma interferon-, or IL-4-secreting splenocytes induced by Candida albicans mannan and/or monophosphoryl lipid A. Infect. Immun. 66, 1392-1399.

16. Marumo, T., T. Nakaki, H. Adachi, H. Esumi, H. Suzuki, T. Saruta and R. Kato. 1993. Nitric oxide synthase mRNA in endothelial cells: synergistic induction by interferongamma, tumor necrosis factor-alpha and lipopolysaccharide and inhibition by dexamethasone. Jpn. J. Pharmacol. 63, 327-334.

17. Medvedev, V., P. Henneke, A. Schromm, E. Lien, R. Ingalls, M. Fenton, D. Golenbock and S. Vogel. 2000. Induction of tolerance to lipopolysaccharide and mycobacterial components in Chinese hamster ovary/CD14 cells is not affected by over expression of Toll-like receptors 2 or 4 . J. Immunol. $167,2257-2267$.

18. Mishell, B. B. and S. M. Shiigi. 1989. Preparation of mouse cell suspensions in selected methods in cellular immunology, pp. 3-27, In Mishell, B. B. and S. M. Shiigi (eds.), W.H. Freeman and company press, San Francisco.

19. Moncada, S., R. M. Palmer and E. A. Higgs. 1991. Nitric oxide: physiology, pathophysiology, and pharmacology. Pharmacol. Rev. 43, 109-142.

20. Munford, R. A. and J. Pugin. 2001. Normal responses to injury prevent systemic inflammation and can be immunosuppressive. Infect. Immun. 69, 5249-5263.

21. Parker, M. M. 1998. Pathophysiology of cardiovascular dysfunction in septic shock. New Horiz. 6, 130-138.

22. Randow, F., W. D. Docke, D. S. Bundschuh, T. Hartung, A. Wendel and H. D. Volk. 1997. In vitro prevention and reversal of lipopolysaccharide desensitization by IFN-gamma, IL-12, and granulocyte-macrophage colony-stimulating factor. J. Immunol. 158, 2911-2918.

23. Randow, F., U. Syrbe, C. Meisel, D. Krausch, H. Zuckermann, C. Platzer and H. D. Volk. 1995. Mechanism of endotoxin desensitization: involvement of interleukin 10 and transforming growth factor beta. J. Exp. Med. 181, 1887-1892.

24. Ross, M. E. and M. A. Caligiuri. 1997. Cytokine-induced apoptosis of human natural killer cells identifies a novel mechanism to regulate the innate immune response. Blood 89, 910-918.

25. Sanchez-Cantu, L., H. N. Rode and N. V. Christou. 1989. 
Endotoxin tolerance is associated with reduced secretion of tumor necrosis factor. Arch. Surg. 124, 1432-1436.

26. Soszynski, D. 2002. Inhibition of nitric oxide synthase delays the development of tolerance to LPS in rats. Physiol. Behav. 76, 159-169.

27. Tracey, K. J. and A. Cerami. 1993. Tumor necrosis factor: an updated review of its biology. Crit. Care Med. 21, S415-422.

28. Tsujimoto, M., Y. K. Yip and J. Vilcek. 1986. Interferon-gamma enhances expression of cellular receptors for tumor necrosis factor. J. Immunol. 136, 2441-2444.

29. Varma, T. K., T. E. Toliver-Kinsky, C. Y. Lin, A. P. Koutrouvelis, J. E. Nichols and E. R. Sherwood. 2001. Cellular mechanisms that cause suppressed gamma interferon secretion in endotoxin-tolerant mice. Infec. Immun. 69,
5249-5263.

30. Vincent, J. L., H. Zhang, C. Szabo' and J. C. Preiser. 2000. Effects of nitric oxide in septic shock. Am. J. Respir. Crit. Care Med. 161, 1781-1785.

31. Wright, B. E. and M. West. 2002. Pathophysiology of sepsis, pp. 53-62, In Windsor, A. (ed.), Sepsis and Multiple Organ Dysfuction: a Multidisciplinary Approach, WB Saunders, New York.

32. Yoza, B., K. LaRue and C. McCall. 1998. Molecular mechanisms responsible for endotoxin tolerance. Prog. Clin. Biol. Res. 397, 209-215.

33. Zuckerman, S. H. and G. F. Evans. 1992. Endotoxin tolerance: in vivo regulation of tumor necrosis factor and interleukin-1 synthesis is at the transcriptional level. Cell Immunol. 140, 513-519.

\section{초록 : 내독소내성 마우스에서 Nitric Oxide 생성에 미치는 림프구 부전}

길영기··강미경 ${ }^{1} \star$

(고신대학교 의과대학 해부학교실, ${ }^{1}$ 고신대학교 의과대학 의과학연구소)

본 연구에서는 내독소내성 상태에 있는 마우스 세포의 싸이토카인 생성능을 측정하기 위하여 대식세포-림프구 공동배양계를 이용한 nitric oxide $(\mathrm{NO})$ 생성을 조사하였다. 마우스 복강 대식세포에 lipopolysaccharide (LPS)와 interferon-g (IFN-g)를 처리시 NO 생성이 증가되었으며, tumor necrosis factor-a (TNF-a) 또한 LPS처럼 NO 합성을 자극하는 것을 관찰할 수 있었다. 한편, 대식세포를 비장세포와 공동배양시, LPS 단독처리만으로도 NO 합성이 증가되었다. 반면, $2.5 \mathrm{mg} / \mathrm{kg}$ LPS로 전처리하고 치사량의 LPS를 2차 투여한 마우스의 경우, 마우스의 치사 및 혈중 TNF-a와 IFN-g가 증가되지 않았다. 또한 LPS-내성 마우스로부터 분리한 대식세포를 정상 비장세포와 공동배 양시 LPS에 의한 NO생성이 일어나지 않았으며, 외래 TNF-a에 의한 NO 생성도 일어나지 않았다. 이와 아울러 정상 대식세포와 LPS 내성 마우스로부터 분리한 비장세포를 공동배양하였을 때, LPS 자극으로 인한 NO 생성이 일어나지 않았으며, 이러한 억제현상은 외래 IFN-g 또는 IFN-g 생성을 촉진시키는 concanavalin A (ConA)에 의해 서 다시 역전되었다. 이러한 결과는 대식세포 뿐만 아니라 림프구도 LPS 내성에 관여하는 것을 보여준다고 사료된 다. INF-g는 TNF-a 발현을 증가시키기 때문에, 림프구의 INF-g 합성 감소는 LPS에 내성을 보이는 대식세포의 TNF-a 합성 저하와 상호작용으로 내독소내성 상태를 유도하며 과도한 염증반응을 억제하는 것으로 사료된다. 따라서 LPS 내독소내성은 중환자의 심각한 패혈증에 대한 예방법으로 활용될 수 있을 것으로 기대된다. 